\title{
Targeted next-generation sequencing helps to decipher the genetic and phenotypic heterogeneity of hypertrophic cardiomyopathy
}

\author{
MASSIMILIANO CECCONI $^{1}$, MARIA I. PARODI ${ }^{1}$, FRANCESCO FORMISANO $^{2}$, PAOLO SPIRITO ${ }^{2}$, \\ CAMILLO AUTORE $^{3}$, MARIA B. MUSUMECI $^{3}$, STEFANO FAVALE $^{4}$, CINZIA FORLEO $^{4}$, CLAUDIO RAPEZZI $^{5}$, \\ ELENA BIAGINI $^{5}$, SABRINA DAVİ ${ }^{1}$, ELISABETTA CANEPA ${ }^{1}$, LOREDANA PENNESE $^{1}$, MAURO CASTAGNETTA ${ }^{1}$, \\ DARIO DEGIORGIO $^{1,6}$ and DOMENICO A. COVIELLO ${ }^{1}$; COLLABORATIVE WORKING GROUP* \\ ${ }^{1}$ Laboratory of Human Genetics, ${ }^{2}$ Cardiology Unit, E.O. Ospedali Galliera, Genova; ${ }^{3}$ Cardiology Unit, St. Andrea Hospital, \\ Sapienza University, Rome; ${ }^{4}$ Cardiology Unit, Department of Emergency and Organ Transplantation, University of Bari, \\ Bari; ${ }^{5}$ Department of Experimental, Diagnostic and Specialty Medicine, S. Orsola Hospital, University of Bologna, \\ Bologna; ${ }^{6}$ Department of Experimental Medicine, University of Genova, Genova, Italy
}

Received June 1, 2016; Accepted August 16, 2016

DOI: $10.3892 / \mathrm{ijmm} .2016 .2732$

\begin{abstract}
Hypertrophic cardiomyopathy (HCM) is mainly associated with myosin, heavy chain 7 (MYH7) and myosin binding protein $\mathrm{C}$, cardiac $(M Y B P C 3)$ mutations. In order to better explain the clinical and genetic heterogeneity in HCM patients, in this study, we implemented a target-next generation sequencing (NGS) assay. An Ion AmpliSeq ${ }^{\mathrm{TM}}$ Custom Panel for the enrichment of 19 genes, of which 9 of these did not encode thick/intermediate and thin myofilament (TTm) proteins and, among them, 3 responsible of HCM phenocopy, was created. Ninety-two DNA samples were analyzed by the Ion Personal Genome Machine: 73 DNA samples (training set), previously genotyped in some of the genes by Sanger sequencing, were used to optimize the NGS strategy, whereas 19 DNA samples (discovery set) allowed the evaluation of NGS performance. In the training set, we identified 72 out of 73 expected mutations and 15 additional mutations: the molecular diagnosis was achieved in one patient with a previously wildtype status and the pre-excitation syndrome was explained in another. In the discovery set, we identified 20 mutations, 5 of which were in genes encoding non-TTm proteins, increasing the diagnostic yield by approximately $20 \%$ : a single mutation in genes encoding non-TTm proteins was identified in 2 out of 3 borderline HCM patients, whereas co-occuring mutations in
\end{abstract}

Correspondence to: Dr Dario Degiorgio, Laboratory of Human Genetics, E.O. Ospedali Galliera, Via Volta 6, I-16128 Genova, Italy E-mail: dario_degiorgio@hotmail.com

"Members of the Collaborative Working Group are listed in the Appendix

Key words: Ion Torrent Personal Genome Machine, borderline HCM, hypertrophic cardiomyopathy, next-generation sequencing, thick/intermediate and thin myofilament proteins, non-sarcomeric genes, genetic heterogeneity, phenotypic heterogeneity genes encoding TTm and galactosidase alpha (GLA) altered proteins were characterized in a male with HCM and multiorgan dysfunction. Our combined targeted NGS-Sanger sequencingbased strategy allowed the molecular diagnosis of HCM with greater efficiency than using the conventional (Sanger) sequencing alone. Mutant alleles encoding non-TTm proteins may aid in the complete understanding of the genetic and phenotypic heterogeneity of HCM: co-occuring mutations of genes encoding TTm and non-TTm proteins could explain the wide variability of the HCM phenotype, whereas mutations in genes encoding only the non-TTm proteins are identifiable in patients with a milder HCM status.

\section{Introduction}

Hypertrophic cardiomyopathy (HCM), classically defined as the presence of idiopathic left ventricular hypertrophy, is the most common heritable cardiovascular disease (affecting at least 1 in 500 individuals); it is typically transmitted in an autosomal dominant pattern (1-3); however, sporadic cases associated with de novo mutations $(1,4)$ and patients with maternally-inherited HCM $(5,6)$ have also been reported. HCM is recognized as an important cause of sudden cardiac death (SCD), heart failure and embolic stroke secondary to atrial fibrillation (2).

At present, Online Mendelian Inherithance in Man (OMIM) classifies 25 different HCM phenotypes (http://omim. org/phenotypicSeries/PS192600) that are associated with as many different mutant genes, mostly encoding thick/intermediate and thin myofilament (TTm) proteins of the sarcomere. Disease-causing mutations in myosin, heavy chain 7 (MYH7) and myosin binding protein $\mathrm{C}$, cardiac (MYBPC3) genes, encoding myofilament proteins, represent approximately $70 \%$ of $>1,400$ pathogenic alleles that have been characterized in HCM patients by using Sanger sequencing (2). Pathogenic alleles that do not encode for TTm proteins have also been identified in some HCM patients (7-12). Mutations in the genes, galactosidase alpha $(G L A)$, lysosome-associated membrane protein 2 (LAMP2), and protein kinase AMP-activated non-catalytic 
subunit gamma 2 (PRKAG2), are responsible for distinct metabolic storage disorders with a clinical presentation and pattern of left-ventricular hypertrophy similar to $\operatorname{HCM}(1,3,13)$.

However, pathogenic alleles are not identified in $28-40 \%$ of HCM patients with a family history of HCM and $50-90 \%$ of sporadic HCM cases $(13,14)$. On the other hand, 5-10\% of HCM patients carry more than one mutation affecting one or more different genes (15); these complex genotypes are usually identified in patients with severe left ventricular hypertrophy (16), or with end-stage HCM (17) and in patients with severe manifestations of the disease, including advanced heart failure symptoms and sudden death $(1,14)$.

In addition, the broad genetic and allelic heterogeneity can also be associated with a highly variable clinical phenotype, ranging from asymptomatic forms to sudden cardiac death $(1,13)$, even within the same family and amongst family members that share the same pathogenic allele $(18,19)$.

The conventional Sanger sequencing of single amplicons of sarcomeric genes is labor intensive, time consuming and expensive, showing in a large number of patients a negative test or a positive test, but associated with a low predictive clinical outcome. In consideration of these limitations, it is reasonable to adopt the massively parallel sequencing ability of the Next Generation Sequencing (NGS) technologies to decrease run times, lower the costs, use smaller amounts of genomic DNA (20) and, analyzing a larger number of genes, better decipher the relationship between genetic and phenotypic heterogeneity $(21,22)$. In this context, the NGS methodology is replacing the conventional technology, in particular for the diagnosis of genetic disorders with high genetic heterogeneity that involve the screening of several genes or few genes with large coding region $(23,24)$.

In this study, we used the NGS methodology, applied to the molecular characterization of HCM patients, to determine whether the screening of additional genes encoding non-TTm proteins may contribute to the better clarification of the relationship between the phenotypic and genotypic heterogeneity of HCM.

\section{Patients and methods}

Patients. All patients [n=92; mean age, 44.5 ( \pm 18.7$)$ years; age range, 2-78 years] gave their informed consent to the study that was conducted according to the Declaration of Helsinki. The subjects were recruited between 2007 and 2015 from Italian Cardiology Units and addressed to our Human Genetics Laboratory for molecular diagnosis of HCM. The clinical diagnosis of primary HCM was based on medical history, a physical examination and on the echocardiographic demonstration of a hypertrophied left ventricle (LV) that could not be explained by another cardiac or systemic disease. In adults, a maximal LV wall thickness (LVWT) $\geq 15 \mathrm{~mm}$, or the equivalent relative to the body surface area in children, was considered the determining criterion for HCM; the maximal LVWT between 10 and $14 \mathrm{~mm}$, in conjunction with other features (i.e., family history, electrocardiogram abnormalities) prompted the diagnosis of borderline $\operatorname{HCM}(25,26)$.

The phenocopy of HCM was suspected in the presence of multiorgan involvement. In these cases, a multidisciplinary clinical approach was adopted for the final diagnosis (27).
The genomic DNA of each patient was extracted from peripheral leukocytes, using QIAsymphony S (Qiagen, Hilden, Germany) according to the manufacturer's instructions. Among the 92 DNA samples, 73 were used as a training set to optimize the performance of NGS technology; these DNA samples were already genotyped by the Sanger sequencing of 6 genes encoding TTm proteins [MYH7, MYBPC3, troponin T2, cardiac type (TNNT2), actin, alpha, cardiac muscle 1 (ACTC1), tropomyosin 1 (alpha) (TPM1) and troponin I3, cardiac type $(T N N I 3)](1,3)$ and, where appropriate, another 2 genes encoding myofilament proteins [myosin light chain $(M Y L) 2$ and MYL3] $(1,3)$, or 3 genes (GLA, LAMP2 and PRKAG2) responsible for rare metabolic disorders $(1,3,13)$, were analyzed. This series has 63 DNA samples with mutant genotypes and 10 DNA samples with no previously identified mutations.

Another group of 19 DNA samples was adopted as the discovery set to evaluate the performance of NGS methodology in clinical routine HCM testing.

The clinical parameters (age at onset of HCM, LVWT, automatic implantable cardioverter defibrillator, family history of $\mathrm{HCM} /$ sudden cardiac death, left ventricular ejection fraction and other medical issues) were carefully reviewed for patients belonging at the discovery set and for those of the training set that, after NGS analysis, showed additional mutations in genes originally not analyzed by Sanger sequencing. Among these patients, of which 14 were males and 12 were female, the mean age at onset was $33.6( \pm 19.0)$ years, with an age range of 1-72 years; the mean LVWT was $18.7( \pm 6.6) \mathrm{mm}$ and ranged from 10 to $34 \mathrm{~mm}$; the mean $\operatorname{LVEF}(\%)$ was $59.8( \pm 10.4)$.

Gene panel design. To implement the diagnostic genetic testing for HCM patients using NGS technology, in addition to the 11 genes previously screened, after analyzing the literature, we included additional 8 genes deemed most plausibly involved in the HCM phenotype. Among these, 2 genes encode myofilament proteins [thin: troponin $\mathrm{C}$, slows skeletal and cardiac type (TNNC1); and thick: myosin, heavy chain 6 (MYH6)]; one encodes a protein located in the M-band [myomesin 1 (MYOM 1)] (7); two encode Z-disk constituents [myozenin 2 (MYOZ2) and ankyrin repeat domain $1(A N K R D I)](8,9)$; vinculin $(V C L)$ encodes the main costameric protein (10), calreticulin 3 (CALR3) encodes a $\mathrm{Ca}^{2+}$ sensitive/handling protein (11) and caveolin 3 (CAV3) encodes the major membrane protein of caveolae (12).

An Ion AmpliSeq ${ }^{\mathrm{TM}}$ Custom Panel (IACP) for the mutation screening of these 19 genes was designed using the Ion AmpliSeq Designer (IAD) software v.2.0.3. The design included all the coding exons with additional $10 \mathrm{bp}$ of adjacent intronic regions. Overall, it represented approximately $42 \mathrm{~kb}$ of the target DNA sequence, i.e., 284 exons and 452 amplicons divided into 2 pools of primers for multiplex PCR.

Library preparation and NGS. DNA libraries were prepared using the Ion Ampliseq ${ }^{\mathrm{TM}}$ Library kit 2.0 (Thermo Fisher Scientific, Carlsbad, CA, USA) following the manufacturer's instructions.

Briefly, following quantification with a NanoDrop spectrophotometer (Thermo Fisher Scientific), $10 \mathrm{ng}$ of genomic DNA was used in the multiplex PCR amplification of each of the 2 primer pools. For each sample, the 2 sets of multiplexed 
amplicons were subjected to following steps: partial digestion of the primers and amplicon phosphorylation with $\mathrm{FuPa}$ reagent (Thermo Fisher Scientific), ligation of the barcode adapters and purification by Agencourt ${ }^{\circledR}$ AMPure $^{\circledR}$ XP Reagent (Beckman Coulter, Brea, CA, USA).

All the DNA libraries were quantified by the Agilent High Sensitivity DNA kit on a 2100 Bioanalyzer (Agilent Technologies, Milan, Italy) and a Qubit ${ }^{\circledR} 2.0$ Fluorometer using the dsDNA High Sensitivity assay kit (Thermo Fisher Scientific) before being diluted to a final concentration of $100 \mathrm{pmol} / \mathrm{l}$ in low TE; subsequently, $3 \mu \mathrm{l}$ of each sample were pooled to a final concentration of $100 \mathrm{pmol} / \mathrm{l}$. The final pool was further diluted to a concentration of $12 \mathrm{pmol} / \mathrm{l}$ in water and subjected to emulsion PCR and enrichment of Ion Sphere Particles (ISPs) using the Ion Torrent OneTouch ${ }^{\mathrm{TM}} 2$ system (Thermo Fisher Scientific) according to the manufacturer's instructions; confirmation of template-positive ISPs and validation of enrichment were performed on Qubit ${ }^{\circledR}$ 2.0 Fluorometer using Ion sphere quality control kit (Thermo Fisher Scientific), according to the manufacturer's protocol. Enriched ISPs were loaded on Ion 314 or 316 chips and sequenced on the Ion Torrent Personal Genome Machine (PGM) (both from Thermo Fisher Scientific); the sequencing was performed using the PGM 200 Sequencing kit (Thermo Fisher Scientific).

Bioinformatics analysis. Raw data from PGM sequencing runs were processed using 2 software pipelines, Ion Reporter 4.0 (Thermo Fisher Scientific) and the CLC Genomics Workbench software version 6.5 (CLC Bio, Aarhus, Denmark). Sequencing reads were filtered for low-quality reads, trimmed for adapter sequences and tagged as belonging to the specific patient according to the barcode.

Using the spectrum of the expected mutations in the training set, the parameters for variant calling were established to minimize the number of false-positive results and guarantee the characterization of all the true-positive calls; the following filter thresholds were considered: minimum allele frequency for single-nucleotide polymorphism (SNP) and indel (SNP\% $\geq 20$ ), phred-like quality score of the called variant $(\mathrm{Qcall} \geq 20)$ and depth of coverage (Depth $\geq 20$ ).

Coverage assessment was carried out by the Ion Coverage Analysis plug-in v4.0-r77897 and CLC Bio Coverage statistics module. Moreover, alignments were visually inspected with Integrative Genome Viewer (28) to know the depth of analysis of each single nucleotide of the target region and the information concerning the read of the fragments with forward or reverse primer only.

We considered correctly covered, and hence suitable for mutations analysis, only exons (and their adjacent boundary sequences) with a read depth $>20$ reads (20X) for each targeted nucleotide; in detail, this parameter of coverage was requested for i) the $99 \%$ of the target region with respect to 11 genes previously screened in routine molecular diagnosis by Sanger sequencing; ii) the $95 \%$ of the target region for the remaining 8 genes.

Filtering approach and putative mutations assignment. To distinguish potential disease-causing mutations from common variants with a minor allele frequency $(\mathrm{MAF}) \geq 1 \%$, the nucleotide alterations were initially filtered against the variations reported in dbSNP138 (http://www.ncbi.nlm.nih. gov/SNP/), the HapMap v3.3, the Exome Variant Server (EVS; http://evs.gs.washington.edu/EVS/), the 1000 Genomes Project (www.1000genomes.org) hg19 (patch9) and the Exome Aggregation Consortium (ExAC; exac.broadinstitute.org).

Nonsense, frameshift, canonical splice site $( \pm 2 \mathrm{bp})$ mutations, together with missense mutations already unequivocally described as associated with the HCM phenotype (or with other forms of cardiomyopathies), and reported in the Human Genome Mutation Database (29) (HGMD, http://www.hgmd. org/; release 2015.4) as disease-causing mutations (DM), were considered as 'pathogenic variants'.

To evaluate the effect on protein function of the missense mutations not described in the literature or annotated in HGMD as DM? (DM of questionable pathological relevance), the in silico prediction of pathogenicity was established by Polyphen2 (http://genetics.bwh.harvard.edu/pph2/), Mutation Taster (http://www.mutationtaster.org/) and SIFT human protein (http://sift.jcvi.org/) algorithms. Afterward, we classified these missense mutations either as 'pathogenic variants' when the pathogenic impact was predicted by all algorithms or as 'likely pathogenic variants' when the pathogenic impact was predicted by 2 out of 3 algorithms.

Taking into account the stringent above-mentioned criteria, we evaluated that, in the training set, 67 out of 73 expected mutations were classifiable as 'pathogenic variants', while the remaining 6 were predicted as 'likely pathogenic variants'; of these, 52 mutations were annotated in HGMD.

Sanger sequencing of uncovered regions and validations of putative variants. Using Sanger sequencing, we analyzed the exons classified as uncovered in order to reach the percentage of target region correctly covered; moreover, the new non-synonymous nucleotide variants identified were also confirmed by Sanger sequencing.

In brief, exons containing the nucleotide variants were amplified using Taq Platinum (Invitrogen, Carlsbad, CA, USA) with specific flanking primers and sequenced using Big Dye v3.1 (Thermo Fisher Scientific); fragments of PCR and products of sequencing were purified by Agencourt AMPure XP and CleanSEQ, respectively, on automated station Biomek FX (Beckman Coulter). Sequencing was carried out on 3130 and $3730 \mathrm{xl}$ automated sequencers (Thermo Fisher Scientific). Data analysis was performed using SeqScape v2.5 software (Thermo Fisher Scientific).

The history of atrial fibrillation between the different groups of patients was compared using Fisher's exact test. A p-value $<0.05$ was considered to indicate a statistically significant difference.

\section{Results}

IACP performance. To verify the theoretical coverage of the 19 genes, all 284 coding exons were analyzed with IAD software: 259 (91.2\%) were ascribed to theoretical covered exons. The NGS analysis of the 73 samples (the training set) showed a coverage $>20 \mathrm{X}$ for each target nucleotide into 253 exons (97.7\%) (Table I). The remaining exons were classifiable with unsuitable coverage and therefore were screened by conventional (Sanger) sequencing. 


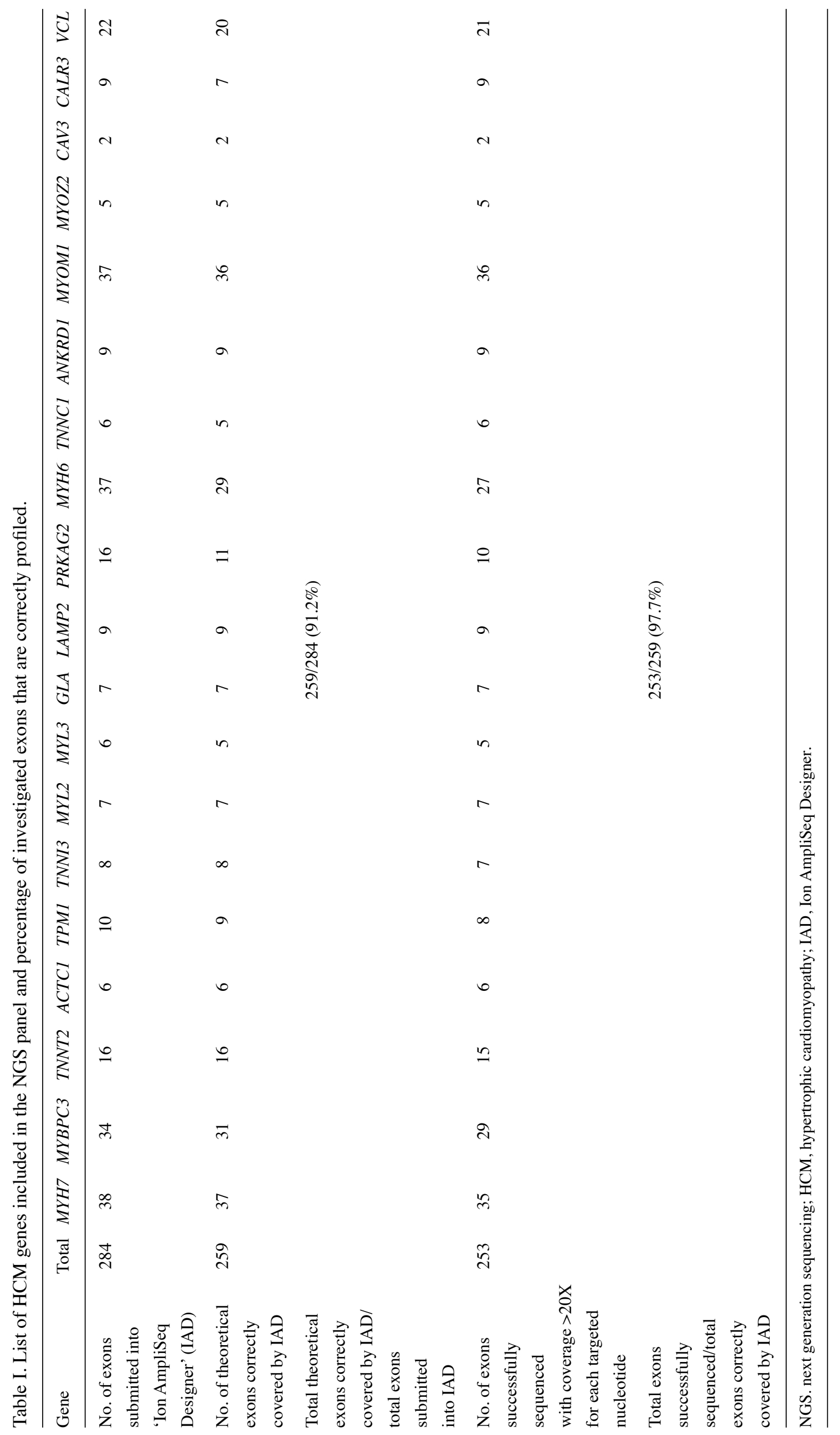



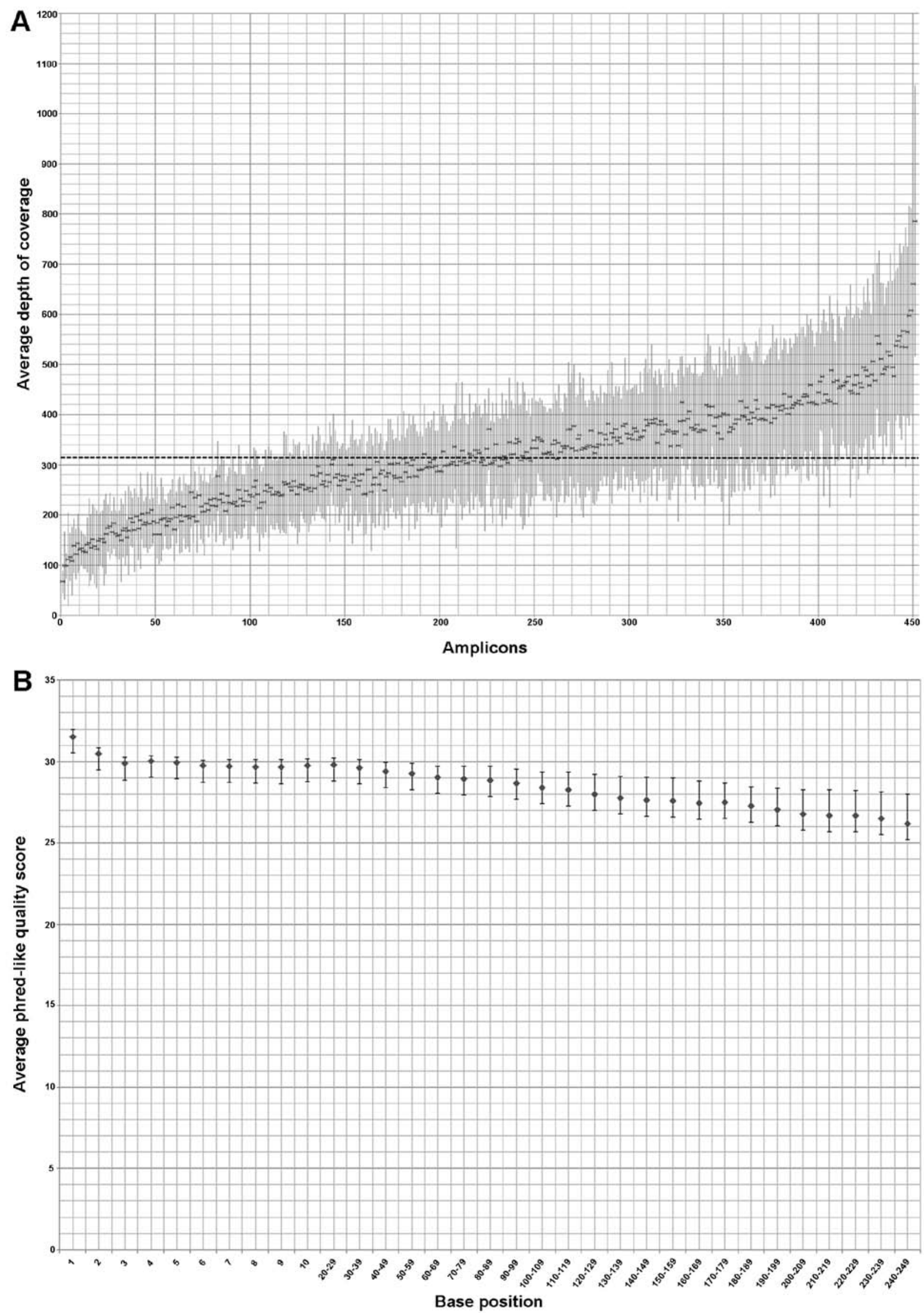

Figure 1. Depth of coverage and phred-like quality score of 73 samples belonging to training set; the dots and the bars represent the mean values and standard deviation, respectively. (A) Distribution of the average depth of coverage of all 452 amplicons (ordered according to the mean coverage, from the least to the most represented in the mean depth of coverage per-amplicon); the dashed line indicates the mean coverage ( $318 \mathrm{X}$ ) concerning the 452 enriched amplicons of all patients. (B) Distribution of the average phred-like quality score related to each base of every amplicon that composes the alignment: the values are included between 26,2 and 31,5. 
The mean depth of coverage per amplicon in the 73 samples of the training set was $318 \mathrm{X}$ and only 21 (4.6\%) out of 452 amplicons showed a mean depth $<150$ reads (Fig. 1A). Six out of the 73 samples had an average read depth $<150 \mathrm{X}$ and, among these, only 2 samples had an average read depth $<100 X$.

The average phred-like quality score respect at each base position of the training set ranged between 26.2 and 31.5, with the minimum and maximum value of the standard deviation equal to 0.41 and 1.79 , respectively (Fig. 1B).

The training set: 'PGM ${ }^{\mathrm{TM}}$ Runs' evaluation in covered regions shows expected and additional mutations. The IACP sequencing of the training set confirmed the presence of 72 out of 73 expected mutations (detection rate of approximately 99\%) with the known allelic status (Table II). In one sample we missed the deletion of the nucleotide at the position 2610 into $M Y B P C 3$ that is located within a homopolymer of 6 cytosines; in addition, in all samples, we observed the false-positive call $M Y H 7: c .136 \mathrm{~T}>\mathrm{C}$.

Furthermore, following 'PGM Runs' evaluation of the genes not previously investigated by Sanger sequencing, we identified 15 additional mutations (Table II) of which 10 were in genes encoding proteins different from (TTms) (4 were in genes encoding a protein located in the M-band, 2 were in encoding Z-disk constituents genes, 2 were in metabolic genes and 2 were in the $C A V 3$ gene). Taking into account the stringent criteria established in the 'Patients and methods' section, 10 out of 15 additional mutations could be ascribed to the category 'pathogenic variants', while the remaining 5 were classified as 'likely pathogenic variants' (Table II).

The training set: the additional mutations are identified in HCM subjects with arrhythmias or with pre-excitation syndrome. The 15 additional mutations belong to 11 out of 73 patients (15\%) (Table III). In 2 patients, we identified only mutations of genes encoding TTm proteins, while in the remaining 9 patients, we characterized co-occurring mutations of genes encoding TTm/non-TTm proteins. Three out of 9 subjects with mutations of genes encoding TTm and non-TTm proteins had a personal history characterized by atrial fibrillation and non-sustained ventricular tachycardia episodes. Additionally, the NGS re-analysis permitted the identification of: i) two mutations in the MYL2 gene in one teenager affected by hypertrophic obstructive cardiomyopathy that initially, following Sanger analysis, was classified as wild-type; ii) the missense mutation LAMP2:p.(Val310Ile), already described as causative of Danon disease, in a young female affected by HCM and with the typical Wolff-Parkinson-White (WPW) electrocardiographic pattern (shortened PR interval and delta wave).

The discovery set: $P G M^{\mathrm{TM}}$ Runs evaluation for 19 HCM-related genes in 19 patients. The IACP sequencing of 19 DNA samples, and the following PGM Runs evaluation for all genes of the panel, allowed the identification of 20 mutations in 7 genes (Table IV).

Thirteen mutations were identified in 2 major sarcomeric genes, $M Y B P C 3$ and $M Y H 7$; all 13 mutations were classified as 'pathogenic variants'.

The remaining 7 mutations were identified in the following genes: i) MYH6 (2 mutations in thick filament); ii) MYOMI (2 mutations in M-band protein); iii) MYOZ2 (one mutation in
Z-disk constituent); iv) GLA and LAMP2 (one mutation each in metabolic genes). Four mutations were classified as 'pathogenic variants' and the remaining 3 were considered as 'likely pathogenic variants'. No false-positive result was identified in our discovery set.

The discovery set: mutations in genes encoding non-TTm proteins are identified in borderline HCM status and in an HCM subject with an extremely complex phenotype. The 20 mutations were identified in 15 out of 19 patients (Table V). A single mutant allele in genes encoding non-TTm proteins was identified in 3 patients without a family history of HCM; by contrast, the 5 patients that had a family history of HCM carried a single mutant allele in genes encoding TTm proteins. Two out of 3 patients with only a single mutant allele in genes (LAMP2 for female patient, MYOM1) encoding non-TTm proteins had a diagnosis of borderline HCM, while the male patient with co-occuring mutations in genes encoding TTm proteins (MYBPC3 and MYH6) and in the GLA gene showed the diagnostic parameter of HCM (LVWT, $19 \mathrm{~mm}$ ) together with a history of atrial fibrillation and multiorgan involvement (skin, eyes, ears and thyroid), typical of Fabry disease of male patients.

\section{Discussion}

Hereditary HCM is historically known as an autosomal dominant disease and is associated mainly with mutations in the MYBPC3 and MYH7 genes. Over the past years, it has become increasingly evident that the same pathogenic mutation, even within the same family, shows a highly variable presentation and clinical course in different individuals $(18,19)$. Contextually, it has been shown that hereditary HCM can also be associated with mutations of genes that do not encode TTm proteins (7-12) and, in some patients, more than one pathogenic mutation has been identified (22). In consideration of this complexity, as well as the possibility of shedding new light on the relationship between the genetic and the phenotypic heterogeneity, in this study, we designed a target NGS panel, using the Ion Torrent PGM system, in order to simultaneously analyze a total of 19 genes encoding not only TTm proteins, but also other sarcomeric proteins and some non-sarcomeric proteins that cause HCM phenocopies $(1,3,13)$.

Our training set allowed us to calibrate the NGS methodology (enrichment, library preparation and bioinformatics analysis parameters). With respect to all 284 coding exons, the coverage at $>20 \mathrm{X}$ depth for each target nucleotide (see Patients and methods) includes 253 out of 259 exons correctly profiled by IAD. This not uniform coverage of our design, as previously reported, could be linked to aspects concerning the target gene enrichment strategy and at the efficiencies of PCR amplification during library preparation (30). It has been reported that regions with high a GC content are more difficult to amplify and, also, the PGM system has showed a poor coverage within AT-rich exonic segments of P. falciparum (31). Additionally, in our NGS gene panel, specific genomic regions, such as those with a high homology of the $M Y H 6$ and $M Y H 7$ genes, contribute greatly to this inadequate coverage.

With respect to the target NGS study by Gómez et al (32), our diagnostic HCM workflow provides the analysis of a larger 
Table II. Pathogenic or likely pathogenic variants identified by Ion AmpliSeq ${ }^{\mathrm{TM}}$ Custom Panel (IACP) sequencing into the training set following Runs evaluation for expected and additional mutations of 73 HCM patients.

\begin{tabular}{|c|c|c|c|c|c|c|c|}
\hline Gene & $\begin{array}{l}\text { Nucleotide } \\
\text { change }\end{array}$ & $\begin{array}{l}\text { Effect on } \\
\text { protein }\end{array}$ & $\begin{array}{c}\text { Annotation }^{\mathrm{b}} \\
\text { (HGMD or } \mathrm{NCBI})\end{array}$ & $\begin{array}{l}\text { Predicted impact } \\
\text { on protein }\end{array}$ & $\begin{array}{c}\text { Variant } \\
\text { frequency }\end{array}$ & Coverage & Q score \\
\hline ACTC1 & c. $707 \mathrm{C}>\mathrm{T}$ & p.(Ser236Phe) & KU324679 (present study) & Pathogenic $^{d}$ & 0.48 & 348 & 31.81 \\
\hline ACTC1 & c. $992 \mathrm{~T}>\mathrm{A}$ & p.(Ile331 Asn) & KU324680 (present study) & Pathogenic $^{\mathrm{d}}$ & 0.48 & 41 & 29.5 \\
\hline$G L A$ & c. $.514 \mathrm{~T}>\mathrm{C}$ & p.(Cys172Arg) & CM003746 [DM] & Pathogenic ${ }^{\mathrm{c}}$ & 0.5 & 1116 & 31.87 \\
\hline GLA & c. $1146 \mathrm{C}>\mathrm{A}$ & p. $($ Cys $382 *)$ & KU508439 (present study) & Pathogenic ${ }^{c}$ & 0.32 & 671 & 25.31 \\
\hline$L A M P 2$ & c. $239 \mathrm{G}>\mathrm{T}$ & p.(Gly80Val) & KU508440 (present study) & Likely pathogenic $^{\mathrm{d}}$ & 0.49 & 271 & 28.6 \\
\hline$L A M P 2$ & c. $741+1 \mathrm{G}>\mathrm{T}$ & Mis-splicing & KU557502 (present study) & Pathogenic ${ }^{c}$ & 0.5 & 177 & 29.23 \\
\hline МYBPC 3 & c. $223 \mathrm{G}>\mathrm{A}$ & p.(Asp75Asn) & HM090070 [DM] & Pathogenic ${ }^{c}$ & 0.46 & 173 & 30.15 \\
\hline МYBPC3 & c. $506-2 \mathrm{~A}>\mathrm{C}$ & Mis-splicing & CS109051 [DM] & Pathogenic $^{c}$ & 0.43 & 191 & 28.22 \\
\hline МYВРС 3 & c. $557 \mathrm{C}>\mathrm{T}$ & p.(Pro186Leu) & CM106110 [DM] & Pathogenic ${ }^{c}$ & 0.42 & 45 & 29.47 \\
\hline МYBPC3 & c. $649 \mathrm{~A}>\mathrm{G}$ & p.(Ser217Gly) & CM109108 [DM?] & Pathogenic $^{\mathrm{d}}$ & 0.48 & 295 & 26.67 \\
\hline МYBPC 3 & c. $772 \mathrm{G}>\mathrm{A}$ & p.(Glu258Lys) & CM981322 [DM] & Pathogenic ${ }^{c}$ & 0.5 & 526 & 30.12 \\
\hline МYBPC 3 & c.913_914delTT & p.(Phe305ProfsX27) & CD086092 [DM] & Pathogenic ${ }^{\mathrm{c}}$ & 0.45 & 410 & 27.48 \\
\hline МYBPCЗ & c. $977 \mathrm{G}>\mathrm{A}$ & p. $(\operatorname{Arg} 326 \mathrm{Gln})$ & CM020155 [DM?] & Likely pathogenic $^{\mathrm{d}}$ & 0.45 & 451 & 27.1 \\
\hline МYBРCЗ & c. $1003 \mathrm{C}>\mathrm{T}$ & p.(Arg335Cys) & KU508441 (present study) & Pathogenic $^{\mathrm{d}}$ & 0.5 & 288 & 31.23 \\
\hline МYBPC 3 & c. $1090 \mathrm{G}>\mathrm{A}$ & p.(Ala364Thr) & CM152770 [DM] & Pathogenic ${ }^{\mathrm{c}}$ & 0.53 & 232 & 27.45 \\
\hline МYВРСЗ & c. $1112 \mathrm{C}>\mathrm{G}$ & p.(Pro371Arg) & CM102043 [DM] & Pathogenic ${ }^{c}$ & 0.47 & 355 & 28.62 \\
\hline МYВРС 3 & c.1174delG & p.(Ala392Leufs*14) & CD086093 [DM] & Pathogenic ${ }^{c}$ & 0.51 & 183 & 26.15 \\
\hline МYВРС 3 & c. $1458-1 \mathrm{G}>\mathrm{A}$ & Mis-splicing & rs397515903 (dbSNP) & Pathogenic ${ }^{c}$ & 0.61 & 241 & 29.65 \\
\hline МYBPC 3 & c. $1505 \mathrm{G}>\mathrm{A}$ & p. (Arg502Gln) & CM981325 [DM] & Pathogenic ${ }^{c}$ & 0.43 & 521 & 30 \\
\hline МYBPC 3 & c. $1564 \mathrm{G}>\mathrm{A}$ & p.(Ala522Thr) & CM057197 [DM] & Pathogenic ${ }^{\mathrm{c}}$ & 0.55 & 182 & 29.82 \\
\hline МYВРCЗ & c. $1591 \mathrm{G}>\mathrm{C}$ & p.(Gly531Arg) & CM068013 [DM] & Pathogenic ${ }^{c}$ & 0.57 & 142 & 26.98 \\
\hline МYBРC3 & c. $1615 A>G$ & p.(Ile539Val) & CM1412245 [DM] & Pathogenic ${ }^{c}$ & 0.51 & 215 & 29.22 \\
\hline МYBPC3 & c. $1624 \mathrm{G}>\mathrm{C}$ & p.(Glu542Gln) & CM971007 [DM] & Pathogenic $^{c}$ & 0.5 & 176 & 32.78 \\
\hline МYВРСЗ & c.1670dup & p.(Ala558Argfs*10) & KU508442 (present study) & Pathogenic ${ }^{\mathrm{c}}$ & 0.54 & 396 & 29.51 \\
\hline МYВРС 3 & c. $1696 \mathrm{~T}>\mathrm{A}$ & p.(Cys566Ser) & KU508443 (present study) & Pathogenic $^{\mathrm{d}}$ & 0.35 & 440 & 28.53 \\
\hline МYBРC 3 & c. $1790 \mathrm{G}>\mathrm{A}$ & p.(Arg597Gln) & CM122972 [DM] & Pathogenic ${ }^{c}$ & 0.51 & 635 & 31.83 \\
\hline МYBPC 3 & c. $2198 \mathrm{G}>\mathrm{A}$ & p.(Arg733His) & CM092564 [DM] & Pathogenic ${ }^{c}$ & 0.44 & 159 & 29.97 \\
\hline МYBPC3 & c.2258dupT & p.(Lys754Glufs*79) & CI063699 [DM] & Pathogenic ${ }^{\mathrm{c}}$ & 0.56 & 167 & 29.6 \\
\hline МYBPCЗ & c. $2309-2 \mathrm{~A}>\mathrm{G}$ & Mis-splicing & CS043648 [DM] & Pathogenic $^{c}$ & 0.48 & 126 & 29.91 \\
\hline МYBPCЗ & c. $2311 \mathrm{G}>\mathrm{A}$ & p.(Val771Met) & CM056362 [DM] & Pathogenic $^{c}$ & 0.52 & 246 & 31.59 \\
\hline МYBРCЗ & c. $2429 \mathrm{G}>\mathrm{A}$ & p.(Arg810His) & CM034546 [DM] & Pathogenic ${ }^{c}$ & 0.26 & 528 & 31.23 \\
\hline МYВРC 3 & c. $2449 \mathrm{C}>\mathrm{G}$ & p.(Arg817Gly) & KU508444 (present study) & Pathogenic $^{\mathrm{d}}$ & 0.42 & 105 & 22.86 \\
\hline МYВРСЗ & c. $2610 \mathrm{del}^{\mathrm{a}}$ & p.(Ser871Alafs*8) & CD0910615 [DM] & Pathogenic ${ }^{\mathrm{c}}$ & - & - & - \\
\hline МYВРС 3 & c. $2618 \mathrm{C}>\mathrm{T}$ & p.(Pro873Leu) & CM116747 [DM] & Pathogenic ${ }^{c}$ & 0.75 & 106 & 24 \\
\hline МYBPC3 & $\begin{array}{l}\text { c. } 2864 \_2865 \\
\text { delCT }\end{array}$ & p.(Pro955Argfs*95) & CD982813 [DM] & Pathogenic $^{c}$ & 0.5 & 599 & 28.31 \\
\hline МYBPC 3 & c. $2906-2 \mathrm{~A}>\mathrm{G}$ & Mis-splicing & KU508445 (present study) & Pathogenic ${ }^{c}$ & 0.46 & 233 & 22.6 \\
\hline МYBPC 3 & c. $2992 \mathrm{C}>\mathrm{G}$ & p.(Gln998Glu) & CM043548 [DM] & Pathogenic $^{c}$ & 0.48 & 120 & 28.12 \\
\hline МYВРСЗ & c. $3065 \mathrm{G}>\mathrm{C}$ & p.(Arg1022Pro) & CM058261 [DM?] & Pathogenic $^{\mathrm{d}}$ & 0.42 & 223 & 27.13 \\
\hline МYBPC3 & c. $3103 \mathrm{G}>\mathrm{A}$ & p.(Ala1035Thr) & rs552505566 (present study) & Likely pathogenic $^{\mathrm{d}}$ & 0.39 & 46 & 31 \\
\hline МYBPCЗ & c.3192dupC & p.(Lys1065Glnfs*12) & CI068119 [DM] & Pathogenic $^{c}$ & 0.51 & 95 & 28.26 \\
\hline МYBРCЗ & c. $3331-1 \mathrm{G}>\mathrm{A}$ & Mis-splicing & KU508446 (present study) & Pathogenic ${ }^{\mathrm{c}}$ & 0.45 & 78 & 30.25 \\
\hline МYВРС 3 & c. $3364 \mathrm{~A}>\mathrm{T}$ & p.(Thr1122Ser) & KU508447 (present study) & Pathogenic $^{\mathrm{d}}$ & 0.6 & 102 & 30.52 \\
\hline МYBРC3 & c. $3370 \mathrm{~T}>\mathrm{C}$ & p.(Cys1124Arg) & CM119645 [DM] & Pathogenic ${ }^{c}$ & 0.55 & 137 & 28.65 \\
\hline МYBPC 3 & c. $3551 \mathrm{C}>\mathrm{A}$ & p.(Thr1184Asn) & CM086857 [DM] & Pathogenic ${ }^{\mathrm{c}}$ & 0.51 & 184 & 29.78 \\
\hline МYBРC3 & c. $3560 \mathrm{~T}>\mathrm{G}$ & p.(Leu1187Arg) & CM086863 [DM] & Pathogenic ${ }^{\mathrm{c}}$ & 0.48 & 198 & 29.1 \\
\hline МYBPC 3 & c. $3697 \mathrm{C}>\mathrm{T}$ & p. $\left(\mathrm{G} \ln 1233^{*}\right)$ & CM014069 [DM] & Pathogenic ${ }^{\mathrm{c}}$ & 0.48 & 422 & 30.3 \\
\hline МYBPC 3 & c. $3775 \mathrm{C}>\mathrm{T}$ & p. $(\mathrm{G} \ln 1259 *)$ & KU508448 (present study) & Pathogenic ${ }^{\mathrm{c}}$ & 0.5 & 263 & 23.1 \\
\hline
\end{tabular}


Table II. Continued.

\begin{tabular}{|c|c|c|c|c|c|c|c|}
\hline Gene & $\begin{array}{l}\text { Nucleotide } \\
\text { change }\end{array}$ & $\begin{array}{l}\text { Effect on } \\
\text { protein }\end{array}$ & $\begin{array}{c}\text { Annotation }^{\mathrm{b}} \\
\text { (HGMD or NCBI) }\end{array}$ & $\begin{array}{c}\text { Predicted impact } \\
\text { on protein }\end{array}$ & $\begin{array}{l}\text { Variant } \\
\text { frequency }\end{array}$ & Coverage & Q score \\
\hline MYH7 & c. $676 \mathrm{G}>\mathrm{A}$ & p.(Ala226Thr) & KU319883 (present study) & Likely pathogenic ${ }^{\mathrm{d}}$ & 0.54 & 120 & 26.77 \\
\hline МYH7 & c. $1208 \mathrm{G}>\mathrm{A}$ & p.(Arg403Gln) & CM900168 [DM] & Pathogenic ${ }^{c}$ & 0.5 & 418 & 31.68 \\
\hline МYH7 & c. $1549 \mathrm{C}>\mathrm{A}$ & p.(Leu517Met) & CM034554 [DM] & Pathogenic $^{c}$ & 0.49 & 201 & 26.95 \\
\hline MYH7 & c. $1988 \mathrm{G}>\mathrm{A}$ & p.(Arg663His) & CM993620 [DM] & Pathogenic $^{c}$ & 0.49 & 247 & 28.56 \\
\hline MYH7 & c. $2102 \mathrm{G}>\mathrm{A}$ & p.(Gly701Asp) & KU508453 (present study) & Pathogenic $^{\mathrm{d}}$ & 0.51 & 431 & 32.93 \\
\hline MYH7 & c. $2804 \mathrm{~A}>\mathrm{T}$ & p.(Glu935Val) & KU508449 (present study) & Pathogenic $^{\mathrm{d}}$ & 0.62 & 174 & 32.51 \\
\hline MYH7 & c. $2890 \mathrm{G}>\mathrm{C}$ & p.(Val964Leu) & CM087588 [DM?] & Pathogenic $^{\mathrm{d}}$ & 0.42 & 179 & 27.32 \\
\hline MYH7 & c. $3113 \mathrm{~T}>\mathrm{C}$ & p.(Leu1038Pro) & CM095777 [DM] & Pathogenic $^{c}$ & 0.5 & 194 & 28.45 \\
\hline MYH7 & c. $3133 \mathrm{C}>\mathrm{T}$ & p.(Arg1045Cys) & CM086874 [DM] & Pathogenic ${ }^{c}$ & 0.48 & 159 & 27.57 \\
\hline МYH7 & c. $3236 \mathrm{G}>\mathrm{A}$ & p.(Arg1079Gln) & CM102044 [DM] & Pathogenic $^{\mathrm{c}}$ & 0.51 & 129 & 31.65 \\
\hline MYH7 & c. $4040 \mathrm{~A}>\mathrm{G}$ & p.(Tyr1347Cys) & KU508450 (present study) & Pathogenic $^{\mathrm{d}}$ & 0.5 & 202 & 29.54 \\
\hline MYH7 & c. $4348 \mathrm{G}>\mathrm{A}$ & p.(Asp1450Asn) & CM122821 [DM] & Pathogenic $^{c}$ & 0.41 & 51 & 27.85 \\
\hline МYH7 & c. $4472 \mathrm{C}>\mathrm{G}$ & p.(Ser1491Cys) & CM050712 [DM?] & Likely pathogenic $^{\mathrm{d}}$ & 0.52 & 522 & 28.63 \\
\hline МYH7 & c. $4690 \mathrm{G}>\mathrm{A}$ & p.(Glu1564Lys) & KU508451 (present study) & Likely pathogenic $^{\mathrm{d}}$ & 0.25 & 522 & 28.46 \\
\hline MYH7 & c. $5287 \mathrm{G}>\mathrm{A}$ & p.(Ala1763Thr) & CM1411014 [DM] & Pathogenic $^{c}$ & 0.49 & 348 & 30.56 \\
\hline PRKAG2 & c. $905 \mathrm{G}>\mathrm{A}$ & p.(Arg302Gln) & CM011949 [DM] & Pathogenic $^{c}$ & 0.51 & 438 & 22.13 \\
\hline TNNI3 & c. $220 \mathrm{C}>\mathrm{G}$ & p.(Arg74Gly) & KU508452 (present study) & Pathogenic $^{\mathrm{d}}$ & 0.22 & 362 & 26.83 \\
\hline TNNI3 & c. $439 \mathrm{G}>\mathrm{C}$ & p.(Val147Leu) & CM1411021 [DM] & Pathogenic $^{\mathrm{c}}$ & 0.99 & 538 & 26.04 \\
\hline TNNI3 & c. $485 \mathrm{G}>\mathrm{A}$ & p. $(\operatorname{Arg} 162 \mathrm{Gln})$ & CM034575 [DM] & Pathogenic ${ }^{c}$ & 0.57 & 234 & 28.55 \\
\hline TNNI3 & c. $581 \mathrm{~A}>\mathrm{G}$ & p.(Asn194Ser) & CM1414551 [DM] & Pathogenic $^{c}$ & 0.56 & 178 & 27.41 \\
\hline TNNT2 & c. $83 \mathrm{C}>\mathrm{T}$ & p.(Ala28Val) & CM063210 [DM] & pathogenic ${ }^{c}$ & 0.52 & 174 & 26.89 \\
\hline TNNT2 & c. $247 \mathrm{G}>\mathrm{A}$ & p.(Glu83Lys) & CM034581 [DM] & Pathogenic $^{c}$ & 0.46 & 307 & 32.69 \\
\hline TNNT2 & c. $275 \mathrm{G}>\mathrm{A}$ & p.(Arg92Gln) & CM951218 [DM] & Pathogenic $^{\mathrm{c}}$ & 0.46 & 897 & 25.98 \\
\hline TNNT2 & c. $.536 \mathrm{C}>\mathrm{T}$ & p.(Ser179Phe) & CM002871 [DM] & Pathogenic $^{c}$ & 0.5 & 699 & 26.38 \\
\hline TNNT2 & c. $832 \mathrm{C}>\mathrm{T}$ & p.(Arg278Cys) & CM951222 [DM] & Pathogenic ${ }^{\mathrm{c}}$ & 0.6 & 126 & 29.11 \\
\hline TPM1 & c. $644 \mathrm{C}>\mathrm{T}$ & p.(Ser215Leu) & CM087722 [DM] & Pathogenic $^{c}$ & 0.46 & 669 & 26.13 \\
\hline MYOM1 & c.139A $>$ G & p.(Ser47Gly) & rs202145133 (dbSNP) & Likely pathogenic $^{\mathrm{d}}$ & 0.37 & 50 & 25.25 \\
\hline MYOMI & c. $1514 A>C$ & p.(Glu505Ala) & KU508437 (present study) & Likely pathogenic $^{\mathrm{d}}$ & 0.58 & 68 & 27.97 \\
\hline MYOMI & c. $2087 \mathrm{G}>\mathrm{A}$ & p.(Arg696His) & KU508438 (present study) & Pathogenic $^{\mathrm{d}}$ & 0.51 & 662 & 31.44 \\
\hline MYOMI & c. $2110 G>A$ & p.(Glu704Lys) & rs149528866 (dbSNP) & Likely pathogenic ${ }^{\mathrm{d}}$ & 0.47 & 258 & 27.57 \\
\hline МYH6 & c. $3883 G>C$ & p.(Glu1295Gln) & rs34935550 (dbSNP) & Pathogenic $^{\mathrm{d}}$ & 0.46 & 74 & 28.3 \\
\hline MYH6 & $\begin{array}{l}\text { 5476_5477del } \\
\text { GGinsAA }\end{array}$ & p.(Gly1826Asn) & CX103031 [DM] & Pathogenic ${ }^{c}$ & 0.3 & 361 & 23.38 \\
\hline МYH6 & c.5797-2A>G & Mis-splicing & KU508454 (present study) & Pathogenic $^{\mathrm{c}}$ & 0.49 & 424 & 19.97 \\
\hline MYOZ2 & c. $36 \mathrm{~A}>\mathrm{C}$ & p.(Lys12Asn) & KU508455 (present study) & Pathogenic $^{\mathrm{d}}$ & 0.5 & 350 & 30.44 \\
\hline$L A M P 2$ & c.928G $>A$ & p.(Val310Ile) & CM057189 [DM] & Pathogenic ${ }^{c}$ & 0.49 & 103 & 31.68 \\
\hline$C A V 3$ & c. $216 C>G$ & p.(Cys72Trp) & CM980306 [DM] & Pathogenic ${ }^{\mathrm{c}}$ & 0.31 & 393 & 27.2 \\
\hline$C A V 3$ & c. $233 C>T$ & p.(Thr78Met) & CM065052 [DM] & Pathogenic ${ }^{c}$ & 0.49 & 712 & 31.89 \\
\hline ANKRDI & c.827C $>\mathrm{T}$ & p.(Ala276Val) & CM095438 [DM?] & Likely pathogenic ${ }^{\mathrm{d}}$ & 0.51 & 330 & 30 \\
\hline$M Y L 2$ & c. $206 \mathrm{~T}>\mathrm{C}$ & p.(Met69Thr) & KU319885 (present study) & Pathogenic $^{\mathrm{d}}$ & 0.46 & 315 & 31.78 \\
\hline MYL2 & c. $401 \mathrm{~A}>\mathrm{C}$ & p.(Glu134Ala) & CM086879 [DM] & Pathogenic $^{c}$ & 0.51 & 438 & 22.13 \\
\hline$G L A$ & c.937G $>\mathrm{T}$ & p.(Asp313Tyr) & CM930335 [DM?] & Likely pathogenic ${ }^{\mathrm{d}}$ & 1 & 517 & 25.61 \\
\hline
\end{tabular}

${ }^{a}$ Undetected mutation after NGS analysis. ${ }^{b}$ Reference nucleotide data: starting with $\mathrm{CM} / \mathrm{CX} / \mathrm{CI} / \mathrm{CD} / \mathrm{CS} / \mathrm{HM}$ for variants annotated in HGMD; starting with KU/rs for variants annotated in NCBI (GenBank, accession no./dbSNP). 'Mutations annotated in Human Genome Mutation Database (HGMD, http://www.hgmd.org/; release 2015.4) as DM (disease-causing mutations) and nonsense, frameshift, canonical splice site ( \pm 2 bp) mutations identified in this study (or annotated only in dbSNP) were classified as 'pathogenic'. 'The missense mutations not annotated in HGMD and those described as 'DM of questionable pathological relevance' (DM?) were classified as i) 'pathogenic variants' if the pathogenic impact was predicted by all algorithms; ii) 'likely pathogenic variants' if the pathogenic impact was predicted by two out of three algorithms. Bold font indicates the additional mutations identified only by NGS analysis. NGS, next generation sequencing; HCM, hypertrophic cardiomyopathy. 


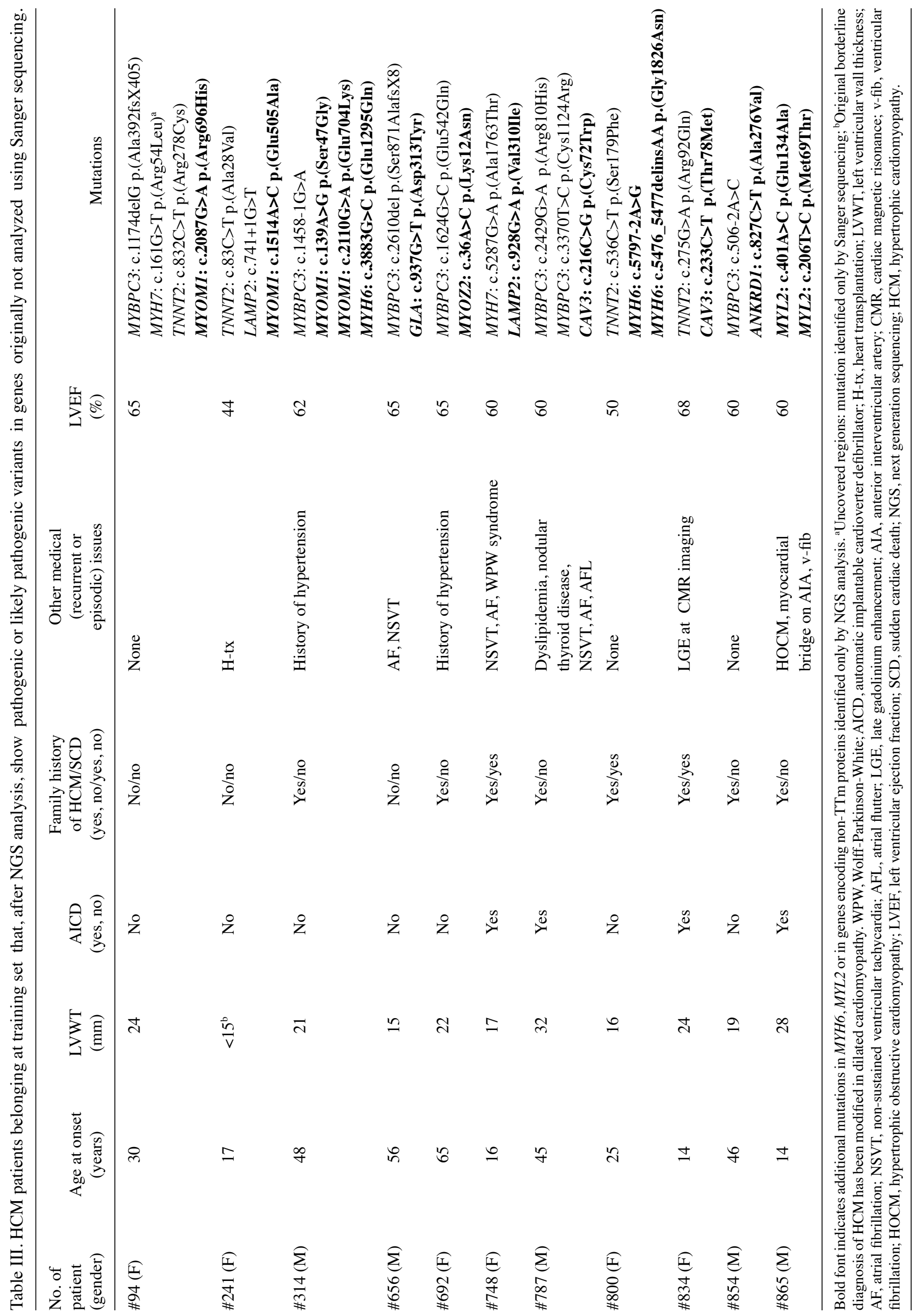




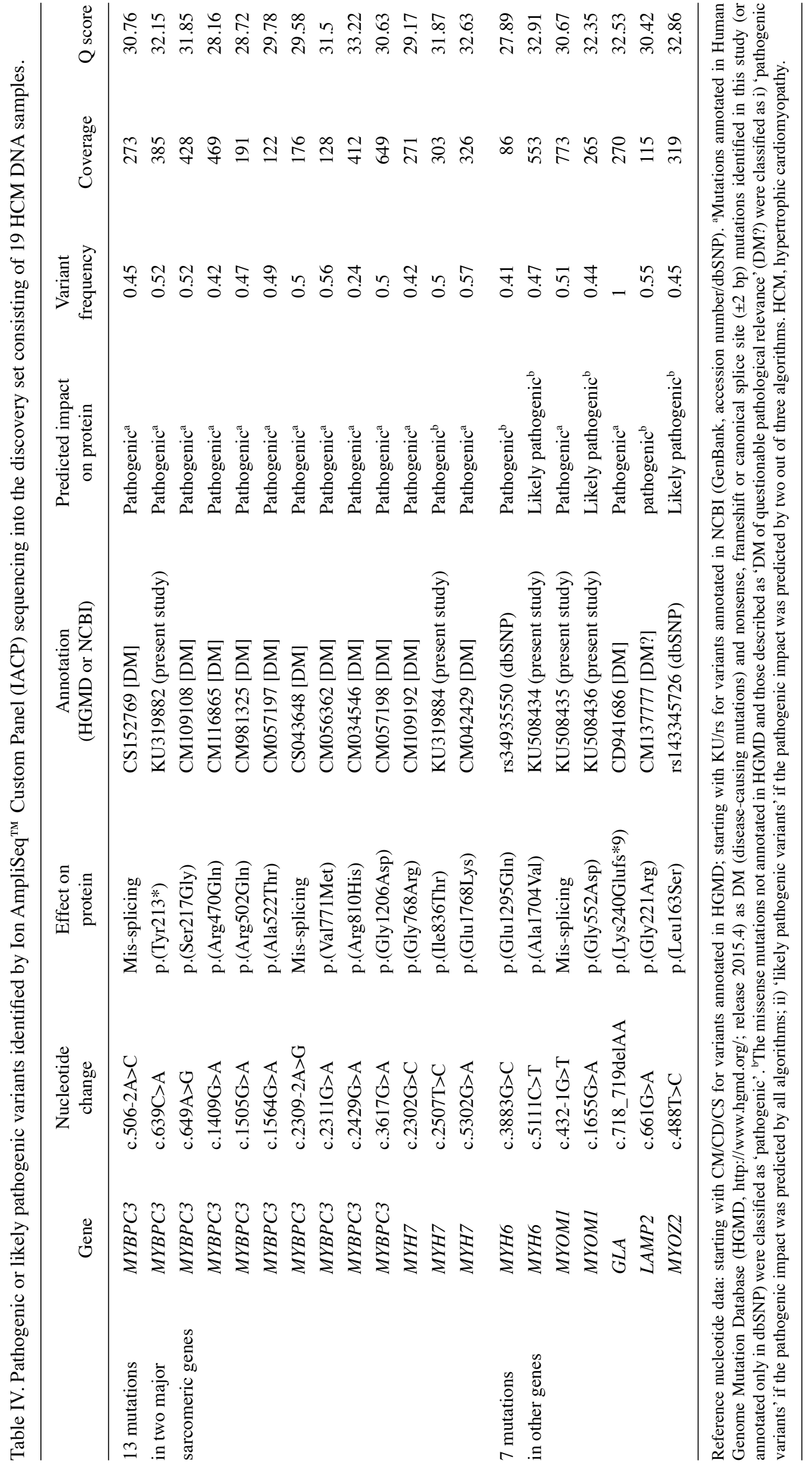




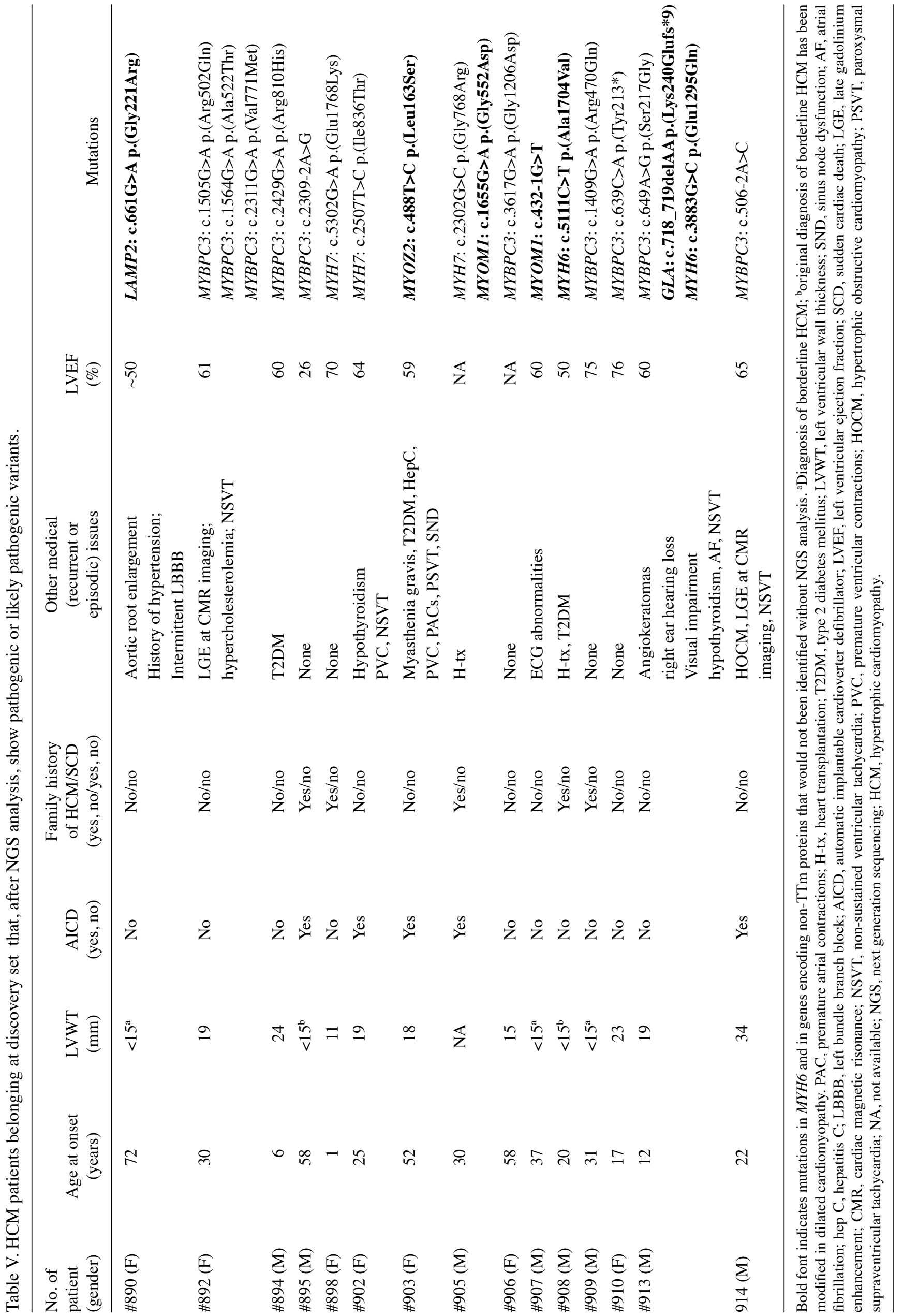


number of genes, including some which encode for proteins different from myofilaments of the sarcomere and 3 genes responsible for the HCM phenocopy. Moreover, through a combined strategy with Sanger sequencing, we ensured a depth of coverage $>20 \mathrm{X}$ for each target nucleotide; other studies $(15,33)$ have reported a higher coverage depth, but only as a general mean coverage.

According to the training set analysis, we observed only one false-negative: our non-identified mutation is located into a short homopolymer region that, as has already been reported (31), represents a DNA motif particularly prone to this error, as in these regions, there is not a linear correlation of $\mathrm{pH}$ between signal-generated and the number of nucleotides incorporated; the only false-positive call $M Y H 7: c .136 \mathrm{~T}>\mathrm{C}$ was already reported in another study (32) and it is located in the first coding exon that had inappropriate coverage and hence, was necessarily analyzed by Sanger sequencing.

Our target NGS panel, applied to the training set encompassing 73 patients, allowed the identification of 15 additional mutations in 11 patients (Table III); these mutations were characterized in genes originally not analyzed by Sanger sequencing: 10 belong to genes encoding proteins of the sarcomere different from (TTms) and, of these, 4 are mutant alleles of the $M Y O M 1$ gene that have previously been associated with HCM in a single study (7). One out of 10 patients, that originally showed wild-type status after Sanger analysis, carried 2 pathogenic alleles in the MYL2 gene that could support the molecular diagnosis of hereditary HCM, whereas for the remaining 10 out of 63 patients, the newly identified mutation (that represents the co-occuring mutation together with other already described as causative of HCM) could contribute as a modifier of the clinical picture in the affected patients of each HCM family $(3,16,22,33)$; for example, the WPW electrocardiographic pattern of patient \#748 (female), that carries a mutant allele in the genes LAMP2 (X-linked) and $M Y H 7$, has already been documented by Cheng et al (34) in some patients with Danon disease and mutation in the $L A M P 2$ gene.

Our target NGS panel, applied to the discovery set, allowed the identification of 20 mutations in 15 patients (Table V). If the molecular characterization of these patients was performed with the older diagnostic workflow, a mutant allele would have been identified only in 11 patients, as the analysis of LAMP2 and GLA genes would have had to be specifically requested and the Sanger assay did not include the screening of the MYOM1, MYOZ2 and MYH6 genes.

The evaluation of the discovery set, even though it is represented by only 15 patients with mutations, seems to suggest that the presence of only one mutant allele in genes encoding non-TTm proteins (LAMP2, MYOM1 and MYOZ2) is associated with a milder HCM status: 2 out of 3 patients had a diagnosis of borderline HCM and none of these 3 patients had a family history of HCM or SCD; at the same time, mutations in genes encoding TTm proteins have been identified in all patients that had a family history of HCM and in only one patient with a diagnosis of borderline HCM. Consistent with the findings of larger studies on genotype-phenotype correlations $(35,36)$, although this study did not have this objective, we found that patients without myofilament mutations, encompassing a female subject with single mutant allele in the LAMP2 (X-linked) gene, show a less severe phenotype.
Interestingly, among the 26 patients of which we report the clinical data, 4 out of $10 \mathrm{HCM}$ subjects with concomitant mutations in genes encoding TTm and non-TTm proteins have also had a history of atrial fibrillation; although, this small sample can only suggest a trend, when the arrhythmia was compared between this subset of patients and the remaining 16 subjects carrying mutations in genes encoding TTm (13 patients) or non-TTm proteins (3 patients) only, the distribution was significantly different (Fisher's exact test, $\mathrm{p}<0.05$ ).

Our data suggest that the screening of new genes using the NGS methodology increases the number of identified mutations. In particular, the discovery set has allowed us to increase the diagnostic yield from 58 to $79 \%$. Additionally, with respect to the Sanger sequencing, the genotyping of the discovery set with NGS methodology has allowed a reduction in turnaround-time for HCM of approximately $75 \%$.

Therefore, in our new diagnostic workflow, including the screening of genes encoding non-TTm proteins, despite the drawback represented by the need to combine targeted NGS and Sanger sequencing in order to obtain a depth of coverage $>20 \mathrm{X}$ for each target nucleotide, the use of the Ion PGM system has showed the following advantages: i) an important decrease in the turn-around-time; ii) an increase in the diagnostic yield; iii) the detection of multiple mutations, or single mutant alleles in genes encoding non-TTm proteins, that contribute to better defining the genetic and phenotypic heterogeneity of HCM: mutations in genes encoding only non-TTm proteins seem to show a milder HCM status, whereas co-occuring mutations of genes encoding TTm and non-TTm proteins could explain the wide variability of the HCM phenotype.

Given the complexity of target NGS methodology, and as previously suggested by the guidelines of the American College of Medical Genetics and Genomics (37), when the genetic test is requested for clinical diagnostic purposes, this technique should be performed by highly specialized laboratories, i.e., laboratories with ISO9001 certification and possibly with the professional accreditation (in Italy SIGU-CERT, Italian Society of Human Genetics certification program).

The target NGS methodology, by permitting a more rapid analysis of a large number of causative genes, may prove to be useful in unveiling the significant genetic heterogeneity of this complex disease that, conjugated with the broad phenotypic heterogeneity, may improve genetic counselling and the clinical management of patients.

\section{Acknowledgements}

We are grateful to the patients for their participation in this study. We would like to thank Dr Elena Gennaro, Dr Angela Robbiano and Dr Federico Zara for their contributing to the evaluation of the parameters concerning the NGS data analysis that were applied to the training set. We would also like to thank the Galliera Genetic Bank (Dr Chiara Baldo) [Network of Telethon Genetic Biobanks (supported by the Italian Telethon project no. GTB12001)] for providing us with parts of the specimens.

\section{References}

1. Maron BJ, Maron MS and Semsarian C: Genetics of hypertrophic cardiomyopathy after 20 years: Clinical perspectives. J Am Coll Cardiol 60: 705-715, 2012. 
2. Maron BJ and Maron MS: Hypertrophic cardiomyopathy Lancet 381: 242-255, 2013.

3. Ho CY, Charron P, Richard P, Girolami F, Van SpaendonckZwarts KY and Pinto Y: Genetic advances in sarcomeric cardiomyopathies: State of the art. Cardiovasc Res 105: 397-408, 2015.

4. Watkins H, Anan R, Coviello DA, Spirito P, Seidman JG and Seidman CE: A de novo mutation in alpha-tropomyosin that causes hypertrophic cardiomyopathy. Circulation 91: 2302-2305, 1995.

5. Casali C, d'Amati G, Bernucci P, DeBiase L, Autore C, Santorelli FM, Coviello D and Gallo P: Maternally inherited cardiomyopathy: Clinical and molecular characterization of a large kindred harboring the $\mathrm{A} 4300 \mathrm{G}$ point mutation in mitochondrial deoxyribonucleic acid. J Am Coll Cardiol 33: 1584-1589, 1999.

6. Hagen CM, Aidt FH, Havndrup O, Hedley PL, Jensen MK Kanters JK, Pham TT, Bundgaard $\mathrm{H}$ and Christiansen M: Private mitochondrial DNA variants in danish patients with hypertrophic cardiomyopathy. PLoS One 10: e0124540, 2015.

7. Siegert R, Perrot A, Keller S, Behlke J, MichalewskaWłudarczyk A, Wycisk A, Tendera M, Morano I and Ozcelik C: A myomesin mutation associated with hypertrophic cardiomyopathy deteriorates dimerisation properties. Biochem Biophys Res Commun 405: 473-479, 2011

8. Osio A, Tan L, Chen SN, Lombardi R, Nagueh SF, Shete S, Roberts R, Willerson JT and Marian AJ: Myozenin 2 is a novel gene for human hypertrophic cardiomyopathy. Circ Res 100: 766-768, 2007

9. Arimura T, Bos JM, Sato A, Kubo T, Okamoto H, Nishi H, Harada H, Koga Y, Moulik M, Doi YL, et al: Cardiac ankyrin repeat protein gene (ANKRD1) mutations in hypertrophic cardiomyopathy. J Am Coll Cardiol 54: 334-342, 2009.

10. Vasile VC, Ommen SR, Edwards WD and Ackerman MJ: A missense mutation in a ubiquitously expressed protein, vinculin, confers susceptibility to hypertrophic cardiomyopathy. Biochem Biophys Res Commun 345: 998-1003, 2006.

11. Chiu C, Tebo M, Ingles J, Yeates L, Arthur JW, Lind JM and Semsarian C: Genetic screening of calcium regulation genes in familial hypertrophic cardiomyopathy. J Mol Cell Cardiol 43: 337-343, 2007.

12. Hayashi T, Arimura T, Ueda K, Shibata H, Hohda S, Takahashi M, Hori H, Koga Y, Oka N, Imaizumi T, et al: Identification and functional analysis of a caveolin-3 mutation associated with familial hypertrophic cardiomyopathy. Biochem Biophys Res Commun 313: 178-184, 2004

13. Gersh BJ, Maron BJ, Bonow RO, Dearani JA, Fifer MA, Link MS, Naidu SS, Nishimura RA,OmmenSR, RakowskiH, et al; American College of Cardiology Foundation/American Heart Association Task Force on Practice Guidelines; American Association for Thoracic Surgery; American Society of Echocardiography; American Society of Nuclear Cardiology; Heart Failure Society of America; Heart Rhythm Society; Society for Cardiovascular Angiography and Interventions; Society of Thoracic Surgeons: 2011 ACCF/AHA guideline for the diagnosis and treatment of hypertrophic cardiomyopathy: executive summary: a report of the American College of Cardiology Foundation/American Heart Association Task Force on Practice Guidelines. Circulation 124 2761-2796, 2011

14. Ingles J, Sarina T, Yeates L, Hunt L, Macciocca I, McCormack L, Winship I, McGaughran J, Atherton J and Semsarian C: Clinical predictors of genetic testing outcomes in hypertrophic cardiomyopathy. Genet Med 15: 972-977, 2013.

15. Meder B, Haas J, Keller A, Heid C, Just S, Borries A, Boisguerin V, Scharfenberger-Schmeer M, Stähler P, Beier M, et al: Targeted next-generation sequencing for the molecular genetic diagnostics of cardiomyopathies. Circ Cardiovasc Genet 4: 110-122, 2011.

16. Zou Y, Wang J, Liu X, Wang Y, Chen Y, Sun K, Gao S, Zhang C, Wang Z, Zhang Y, et al: Multiple gene mutations, not the type of mutation, are the modifier of left ventricle hypertrophy in patients with hypertrophic cardiomyopathy. Mol Biol Rep 40: 3969-3976, 2013

17. Biagini E, Olivotto I, Iascone M, Parodi MI, Girolami F, Frisso G, Autore C,Limongelli G, Cecconi M, Maron BJ, et al: Significance of sarcomere gene mutations analysis in the end-stage phase of hypertrophic cardiomyopathy. Am J Cardiol 114: 769-776, 2014.

18. Roberts WC, Roberts CC, Ko JM, Grayburn PA, Tandon A Kuiper JJ, Capehart JE and Hall SA: Dramatically different phenotypic expressions of hypertrophic cardiomyopathy in male cousins undergoing cardiac transplantation with identical diseasecausing gene mutation. Am J Cardiol 111: 1818-1822, 2013.

19. Landstrom AP and Ackerman MJ: Mutation type is not clinically useful in predicting prognosis in hypertrophic cardiomyopathy. Circulation 122: 2441-2450, 2010.
20. von Bubnoff A: Next-generation sequencing: The race is on Cell 132: 721-723, 2008 .

21. Churko JM, Mantalas GL, Snyder MP and Wu JC: Overview of high throughput sequencing technologies to elucidate molecular pathways in cardiovascular diseases. Circ Res 112: 1613-1623, 2013.

22. Lopes LR, Syrris P, Guttmann OP, O'Mahony C, Tang HC, Dalageorgou C, Jenkins S, Hubank M, Monserrat L, McKenna WJ, et al: Novel genotype-phenotype associations demonstrated by high-throughput sequencing in patients with hypertrophic cardiomyopathy. Heart 101: 294-301, 2015.

23. Morinière V, Dahan $\mathrm{K}$, Hilbert $\mathrm{P}$, Lison $\mathrm{M}$, Lebbah $\mathrm{S}$, Topa $\mathrm{A}$ Bole-Feysot C, Pruvost S, Nitschke P, Plaisier E, et al: Improving mutation screening in familial hematuric nephropathies through next generation sequencing. J Am Soc Nephrol 25: 2740-2751, 2014.

24. Pasmant E, Parfait B, Luscan A, Goussard P, Briand-Suleau A, Laurendeau I, Fouveaut C, Leroy C, Montadert A, Wolkenstein P, et al: Neurofibromatosis type 1 molecular diagnosis: What can NGS do for you when you have a large gene with loss of function mutations? Eur J Hum Genet 23: 596-601, 2015.

25. Spirito P, Autore C, Rapezzi C, Bernabò P, Badagliacca R, Maron MS, Bongioanni S, Coccolo F, Estes NA, Barillà CS, et al: Syncope and risk of sudden death in hypertrophic cardiomyopathy. Circulation 119: 1703-1710, 2009.

26. Authors/Task Force members, Elliott PM, Anastasakis A, Borger MA, Borggrefe M, Cecchi F, Charron P, Hagege AA, Lafont A, Limongelli G, Mahrholdt H, et al: 2014 ESC Guidelines on diagnosis and management of hypertrophic cardiomyopathy: the Task Force for the Diagnosis and Management of Hypertrophic Cardiomyopathy of the European Society of Cardiology (ESC). Eur Heart J 35: 2733-2779, 2014.

27. Rapezzi C, Arbustini E, Caforio AL, Charron P, Gimeno-Blanes J, Heliö T, Linhart A, Mogensen J,Pinto Y, Ristic A, et al: Diagnostic work-up in cardiomyopathies: Bridging the gap between clinical phenotypes and final diagnosis. A position statement from the ESC Working Group on Myocardial and Pericardial Diseases. Eur Heart J 34: 1448-1458, 2013.

28. Thorvaldsdóttir H, Robinson JT and Mesirov JP: Integrative Genomics Viewer (IGV): High-performance genomics data visualization and exploration. Brief Bioinform 14: 178-192, 2013

29. Stenson PD, Mort M, Ball EV, Shaw K, Phillips A and Cooper DN: The Human Gene Mutation Database: Building a comprehensive mutation repository for clinical and molecular genetics, diagnostic testing and personalized genomic medicine. Hum Genet 133: 1-9, 2014.

30. Voelkerding KV, Dames S and Durtschi JD: Next generation sequencing for clinical diagnostics-principles and application to targeted resequencing for hypertrophic cardiomyopathy: A paper from the 2009 William Beaumont Hospital Symposium on Molecular Pathology. J Mol Diagn 12: 539-551, 2010.

31. Quail MA, Smith M, Coupland P, Otto TD, Harris SR, Connor TR, Bertoni A, Swerdlow HP and Gu Y: A tale of three next generation sequencing platforms: Comparison of Ion Torrent, Pacific Biosciences and Illumina MiSeq sequencers. BMC Genomics 13: 341,2012

32. Gómez J, Reguero JR, Morís C, Martín M, Alvarez V, Alonso B, Iglesias S and Coto E: Mutation analysis of the main hypertrophic cardiomyopathy genes using multiplex amplification and semiconductor next-generation sequencing. Circ J 78: 2963-2971, 2014.

33. Lopes LR, Zekavati A, Syrris P, Hubank M, Giambartolomei C, Dalageorgou C, Jenkins S, McKenna W, Plagnol V and Elliott PM; Uk10k Consortium: Genetic complexity in hypertrophic cardiomyopathy revealed by high-throughput sequencing. J Med Genet 50: 228-239, 2013.

34. Cheng Z, Cui Q, Tian Z, Xie H, Chen L, Fang L, Zhu K and Fang Q: Danon disease as a cause of concentric left ventricular hypertrophy in patients who underwent endomyocardial biopsy. Eur Heart J 33: 649-656, 2012.

35. Bos JM, Will ML, Gersh BJ, Kruisselbrink TM, Ommen SR and Ackerman MJ: Characterization of a phenotype-based genetic test prediction score for unrelated patients with hypertrophic cardiomyopathy. Mayo Clin Proc 89: 727-737, 2014.

36. Olivotto I, Girolami F, Ackerman MJ, Nistri S, Bos JM, Zachara E, Ommen SR, Theis JL, Vaubel RA, Re F, et al: Myofilament protein gene mutation screening and outcome of patients with hypertrophic cardiomyopathy. Mayo Clin Proc 83: 630-638, 2008

37. Rehm HL, Bale SJ, Bayrak-Toydemir P, Berg JS, Brown KK, Deignan JL, Friez MJ, Funke BH, Hegde MR and Lyon E; Working Group of the American College of Medical Genetics and Genomics Laboratory Quality Assurance Commitee: ACMG clinical laboratory standards for next-generation sequencing. Genet Med 15: 733-747, 2013 


\section{Appendix}

Members of the Collaborative Working Group that contributed to the study as co-authors: Paolo Di Donna (Cardiology Division, Cardinal G. Massaia Hospital, Asti, Italy); Alessandra Franzoni (Dipartimento di Medicina di Laboratorio, Azienda Ospedaliero-Universitaria S. Maria della Misericordia, Udine, Italy); Teresa Mattina (Department of Pediatrics, Medical Genetics University of Catania, Catania, Italy); Sebastiano Bianca and Chiara Barone (Centro di Consulenza Genetica e Teratologia della Riproduzione, Dipartimento Materno Infantile, ARNAS Garibaldi Nesima, Catania, Italy); Dora Fabbro (Department of Medical and Biological Sciences, University of Udine, Udine, Italy); Stefano Caselli (Institute of Sports Medicine and Science, Rome, Italy); Cesare Renzelli (U.O. Pediatria, Presidio Ospedaliero di Ravenna, Italy); Enrico Grosso (Medical Genetics Unit, 'Città della Salute e della Scienza' University Hospital, Torino, Italy); Patrizio Sarto (UOC of Sport Medicine, ULSS Company 9, Treviso, Italy); Concetta Simona Perrotta (Ambulatorio Genetica Medica, P.O. 'V. Emanuele', Gela, Italy); Carmelo Spadaro (UOC Cardiologia, P.O. 'V. Emanuele', Gela, Italy); Giuseppe Leonardi (UOS Scompenso Cardiaco, Azienda Ospedaliero, Universitaria 'Policlinico-V. Emanuele', Catania, Italy); Demetrio Baldo (Unit of Medical Genetics, ULSS 9 Treviso Hospital, Treviso, Italy); Yana Bettinetti (SSD Cardiologia dipartimento emergenza, Ospedale di Albenga, Italy); Alessandro Nicoletti (UO Pediatria, Ospedale di Bussolengo, Italy); Maria Teresa Ricci (SSD Genetica Medica, AOU San Luigi Gonzaga, Orbassano, Italy); Lucia Baruzzo (ASL2 Savonese, Ospedale San Paolo, Savona, Italy); Alessandro Rimini (Cardiology Unit, IRCCS 'Istituto Giannina Gaslini' Children's Hospital, Genova, Italy); Huei-sheng Vincent Chen (Sanford-Burnham-Prebys Medical Discovery Institute and University of California-San Diego, Departments of Medicine/Cardiology, La Jolla, CA, USA); Conte Maria Rosa (Department of Public Health and Pediatrics, University of Turin, Turin, Italy; Department of Cardiology, Mauriziano Hospital, Turin, Italy). 